\title{
PENGARUH PENAMBAHAN CAMPURAN ASAM AMINO ESENSIAL DAN KOLIN (AMINOVIT) DALAM PAKAN TRADISIONAL TERHADAP PENAMPILAN BABI BALI JANTAN
}

\author{
SUMADI, I K., I M. SUASTA , I P. ARI ASTAWA, A. A. P. P. WIBAWA, DAN A. W. PUGER \\ Fakultas Peternakan Universitas Udayana \\ e-mail: i.k.sumadi@gmail.com
}

\begin{abstract}
ABSTRAK
Penelitian dilakukan bertujuan untuk mengetahui jumlah campuran asam amino esensial dan kolin (Aminovit) yang tepat dalam pakan tradisional pada babi bali jantan lepas sapih yang dipelihara selama 12 minggu. Rancangan yang digunakan adalah rancangan acak lengkap (RAL) dengan empat perlakuan dan setiap perlakuan terdiri atas 4 kali ulangan, sehingga dalam penelitian ini menggunakan $4 \times 4$ ekor $=16$ ekor babi bali jantan lepas sapih dengan kisaran berat badan 11,60-14,10 kg. Perlakuan pakan yang dicobakan yaitu perlakuan Po: pakan dasar campuran 49,5\% jagung kuning dan 49,5\% pollard; P1: perlakuan Po + 0,50\% Aminovit; P2: perlakuan Po + 1,00\% Aminovit; dan P3: perlakuan Po + 1,5 Aminovit. Penampilan yang diamati adalah berat badan awal, berat badan akhir, pertambahan berat badan, konsumsi ransum dan konversi ransum (FCR). Hasil penelitian menunjukkan bahwa peningkatan Aminovit dalam pakan mengakibatkan meningkatnya berat badan akhir, pertambahan berat badan dan konsumsi pakan dan efisiensi penggunaan pakan..
\end{abstract}

Kata kunci: babi bali, pakan, Aminovit, penampilan

\section{THE EFFECTS OF ESSENTIAL AMINO ACID AND CHOLINE MIXTURE (AMINOVIT) SUPLEMENTATION IN TRADITIONAL FEED ON MALE BALI PIGS PERFORMANCE}

\begin{abstract}
This study was conducted to know the right amount of amino acid and choline (Aminovit) mixture in traditional feeds on male bali pigs for 12 weeks. The design used was a completely randomized design (CRD) with four treatments and each treatment consisted of 4 replications, so 16 male bali pigs using with a weight range of 11.60$14.10 \mathrm{~kg}$. The feed treatment were Po treatment: mixed base feed of $49.5 \%$ yellow maize and $49.5 \%$ pollard; P1: treatment Po + 0,50\% Aminovit; P2: Po + 1.00\% Aminovit; and P3: treatment Po + 1.5 Aminovit. The performance measured were initial body weight, final body weight, body weight gain, feed intake, and feed conversion ratio (FCR). The results showed that increasing Aminovite in the feed increased of final body weight, body weight gain and feed consumption, and feed efficiency.
\end{abstract}

Keywords: bali pig, feed, Aminovit, performance

\section{PENDAHULUAN}

Babi bali merupakan ternak andalan petani di perdesaan di Bali yang dipelihara sebagai tabungan (celengan). Menurut beberapa sumber pustaka menyatakan bahwa babi bali sangat baik beradaptasi dengan lingkungan, terutama daerah panas, kurang air dan pakan yang kurang baik. Babi bali merupakan plasma nutfah yang telah dipelihara oleh petani sejak jaman dulu kala di Bali karena bisa beranak banyak antara 8-14 ekor serta dapat dipelihara secara sangat sederhana. Pemeliharaan yang sangat sederhana yang dimaksud adalah bisa diumbar, bisa diikat di bawah pohon serta diberi pakan sisa-sisa dapur. Pada beberapa tahun belakangan ini populasi babi bali menurun dibandingkan dengan populasi babi ras (landrace, large white, duroc), akan tetapi di beberapa daerah yang ketersediaan pakan babi terbatas, suhu udara yang ekstrim dan tidak memungkinkan petani memelihara babi ras, babi bali justru bisa bertahan dengan baik. Karena babi bali masih sangat dibutuhkan oleh konsumen untuk digunakan untuk upacara keagamaan dan yang paling populer adalah untuk babi guling. Kantong-kantong populasi bali seperti di Kecamatan 
Grokgak (Singaraja), Kecamatan Seraya (Karangasem), Kecamatan Manggis (Karangasem), Kecamatan Kubu (Karangasem), di beberapa desa di Kabpeten Jembrana, dan Kecamatan Nusa Penida (Klungkung).

Peternakan babi bali rakyat memanfaatkan sisasisa dapur, daun-daunan, batang pisang, pollard dan bungkil kelapa sebagai bahan pakan ternak. Menurut Nitis (1967) persentase desa yang masyarakatnya memberi pakan babi dari sisa-sisa dapur 95\%; daundaunan $84 \%$; batang pisang $70,88 \%$; pollard $78,82 \%$ dan bungkil kelapa 47,64\%. Telah diketahui bahwa babi bali merupakan babi tipe lemak, tetapi sangat digemari oleh masyarakat Bali karena sangat baik jika digunakan sebagai babi guling, karena disamping rasanya enak juga dagingnya lembut. Sistem peternakan tradisional pada peternakan babi bali yang bercirikan (1) pemberian pakan seadanya; (2) manajemen yang jelek; (3) pencegahan penyakit yang sangat kurang, dan (4) pertumbuan ternak yang sangat lambat. Penelitian terakhir dari Sumadi et al. (2015), mendapatkan bahwa dengan perbaikan nutrisi dalam pakan, maka pertumbuhan babi bali bisa ditingkatkan menjadi o,35$0,5 \mathrm{~kg}$ per hari pada fase pertumbuhan. Pemanfaatan limbah pertanian sebagai pakan babi merupakan hal yang biasa, karena limbah-limbah hasil pertianan dan limbah-limbah industri hasil pertanian tersebut masih kaya akan nutrisi, seperti pollard, bungkil kelapa, pollard, bungkil kedelai, ampas tahu, ampok jagung dan lain sebagainya.

Penelitian mengenai pemberian limbah pembuatan sagu dari batang pohon enau yang di Bali disebut gandos telah dilakukan pada babi bali jantan lepas sapih. Petani di pedesaan sudah biasa memanfaatkan gandos sebagai pakan ternak, terutama itik dan babi (Sumadi et al., 2017). Demikian pula yang lebih penting telah didapatkan sebelumnya bahwa kebutuhan energi dan protein pada babi bali jantan lepas sapih masingmasing sebesar $18 \%$ dan $2950 \mathrm{kkal} \mathrm{ME} / \mathrm{kg}$ (Sumadi et al., 2015).

Asam amino esensial yang dibutuhkan oleh babi sebanyak 10 asam amino. Akan tetapi yang menjadi asam amino esensial yang kandungannya terbatas pada bahan pakan nabati adalah asam amino lisin dan metionin (U.S. Pork Center of Excellence, 2010). Kebutuhan asam amino lisin sekitar 1,25-1,31\% dan kebutuhan asam amino metionin sekitar 0,35-0,37\% dalam pakan pada babi dengan berat badan sekitar 10$15 \mathrm{~kg}$ (U.S. Pork Center of Excellence, 2010; NRC, 2012).

Kolin sangat diperlukan babi muda dan kolin dapat disintesis dari metionin. Hal penting dilakukan untuk meningkatkan kandungan metionin dalam pakan yang kekurangan kolin. Sumber kolin adalah daging dan tepung tulang, kedelai minyak makan, tepung ikan dan biji-bijian. Direkomendasikan bahwa vitamin kolin ditambahan 200 g kolin per ton pakan babi muda, sedangkan pada babi finisher $100 \mathrm{~g}$ per ton pakan. Kandungan kolin dari beberapa bahan pakan seperti jagung kuning $620 \mathrm{mg} / \mathrm{kg}$, pollard $1135 \mathrm{mg} / \mathrm{kg}$ dan tepung ikan $3099 \mathrm{mg} / \mathrm{kg}$ (NRC, 1988).

Kolin merupakan nutrisi penting yang dimasukkan ke dalam golongan vitamin B. Untuk semua kelas babi dibutuhkan kolin untuk proses-proses di dalam tubuh seperti neurotransmisi (asetil kolin), sintesis fosfolipid dan integritas membran sel dan metabolisme lemak dalam tubuh, dan untuk metilasi homosistein menjadi metionin. Kolin penting dalam fungsi saraf, sintesis protein, dan pengembangan struktural di dalam dan kolin dalam arti sempit bukan merupakan vitamin karena babi dapat mensintesis kolin yang cukup untuk kebutuhan mereka, asalkan zat kimia tertentu yang tersedia. Namun, sebagai faktor keamanan, kolin tambahan dianjurkan. Kolin adalah salah satu vitamin yang paling mahal ditambahkan ke daya tahan tubuh. Ini mungkin merupakan 10-25 persen dari biaya suplemen vitamin. Biaya kolin dalam diet kehamilan dapat dibenarkan oleh peningkatan jumlah babi hidup lahir dan disapih ketika ditambahkan pada tingkat 500 gram per ton pakan lengkap (Southern et al., 1986; Patterson et al., 2008).

Pakan tradisional yang diberikan oleh peternak pada babi bali berupa sisa dapur, campuran pollard dan dedak jagung, serta daun-daunan. Pada pakan tradisional ini tidak atau jarang digunakan sumber-sumber asam amino esensial terbatas seperti tepung ikan yang kaya akan lisin dan metionin. Pakan tradisional yang menggunakan pollard dan tepung jagung kalau diberikan kepada babi, sudah tentu kekurangan asam amino lisin dan metionin serta kekurangan kolin.

Penelitian ini dilakukan dengan tujuan untuk mendapatkan jumlah campuran asam amino esensial dan kolin yang pas dalam pakan tradisional pada babi bali jantan lepas sapih yang dipelihara selama 12 minggu. Hal ini akan dapat diketahui dari performans babi bali jantan tersebut setiap bulannya selama penelitian.

\section{METODE PENELITIAN}

\section{Ternak}

Penelitian menggunakan babi bali jantan lepas sapih sebanyak 16 ekor dengan dengan kisaran berat badan 11,60-14,10 kg.. Babi bali jantan lepas sapih tersebut dibeli dari pengepul babi bali yang ada di Desa Grokgak, Kabupeten Buleleng (Bali).

\section{Pakan dan Air Minum}

Bahan-bahan penyusun pakan babi percobaan terdiri atas jagung kuning, pollard, Aminovit, garam dapur 
dan mineral. Sedangkan formulsi pakan (ransum) babi percobaan dengan imbangan $\mathrm{ME} / \mathrm{CP}$ ratio : $2800 \mathrm{kkal} /$ $\mathrm{kg} / 12 \%$, dimana kadar protein ransum diturunkan dari 14\% berdasarkan hasil penelitian Sumadi et al. (2015).

Air minum yang diberi berasal dari air sumur gali setempat. Pakan dan air minum dibei secara ad libitum.

Tabel 1. Komposisi bahan pakan percobaan

\begin{tabular}{lrrrr}
\hline \multirow{2}{*}{ Nama Bahan } & \multicolumn{4}{c}{ Komposisi Pakan (\%) } \\
\cline { 2 - 5 } & \multicolumn{1}{c}{ P0 } & P1 & P2 & P3 \\
\hline Jagung Kuning & 49,5 & 49,5 & 49,5 & 49,5 \\
Pollard & 49,5 & 49,5 & 49,5 & 49,5 \\
Mineral & 0,5 & 0,5 & 0,5 & 0,5 \\
Garam dapur & 0,5 & 0,5 & 0,5 & 0,5 \\
Total & 100 & 100 & 100 & 100 \\
Aminovit & 0 & 0,5 & 1,0 & 1,5 \\
\hline
\end{tabular}

Tabel 2. Komposisi nutrien bahan-bahan pakan percobaan

Bahan pakan ME CP (\%) Lisin Me- Kolin LK SK Ca $\quad$ P

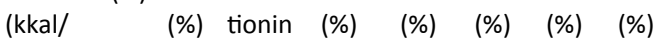
$\mathrm{kg}) \quad(\%)$

\begin{tabular}{lccccccccc}
\multicolumn{1}{c}{} & $\mathrm{kg})$ & \multicolumn{1}{c}{$(\%)$} \\
\hline Jagung kuning & 3420 & 8,3 & 0,23 & 0,17 & 0,062 & 3,9 & 2,3 & 0,03 & 0,28 \\
Pollard & 2275 & 15,7 & 0,64 & 0,25 & 0,1232 & 4,0 & 10 & 0,16 & 1,20 \\
Mineral & - & - & - & - & - & - & - & 44 & 11 \\
Garam & - & - & - & - & - & - & - & - & - \\
\hline
\end{tabular}

Tabel 3. Komposisi $1 \mathrm{~kg}$ bahan dan nutrien Aminovit

\begin{tabular}{lccc}
\hline \multirow{2}{*}{ Bahan } & \multicolumn{3}{c}{ Komposisi } \\
\cline { 2 - 4 } & Bahan $(\mathrm{kg})$ & Nutrien $(\%)$ & Nutrien $(\mathrm{kg})$ \\
\hline Lisin & 0,800 & 79 & 0,632 \\
Metionin & 0,185 & 99,9 & 0,183 \\
Kolin & 0,15 & 60,5 & 0,091 \\
Jumlah & 1,000 & - & - \\
\hline
\end{tabular}

Tabel 4. Komposisi nutrien pakan percobaan

\begin{tabular}{|c|c|c|c|c|c|}
\hline \multirow{2}{*}{$\begin{array}{l}\text { Nama } \\
\text { Nutrien }\end{array}$} & \multicolumn{4}{|c|}{ Pakan } & \multirow{2}{*}{$\begin{array}{l}\text { Kebu- } \\
\text { tuhan } 1\end{array}$} \\
\hline & PO & P1 & P2 & P3 & \\
\hline $\begin{array}{l}\text { Energi/ME } \\
\text { (kkal/kg) }\end{array}$ & 2819 & 2819 & 2819 & 2819 & 3265 \\
\hline PK (\%) & 11,88 & 11,88 & 11,88 & 11,88 & 20,9 \\
\hline LK (\%) & 3,91 & 3,91 & 3,91 & 3,91 & - \\
\hline SK (\%) & 6,09 & 6,09 & 6,09 & 6,09 & - \\
\hline $\mathrm{Ca}(\%)$ & 0,31 & 0,31 & 0,31 & 0,31 & 0.70 \\
\hline $\mathrm{P}(\%)$ & 0,78 & 0,78 & 0,78 & 0,78 & 0,60 \\
\hline Lisin $(\%$ & 0,45 & 0,45 & 0,45 & 0,45 & 1,15 \\
\hline Metionin (\%) & 0,21 & 0,21 & 0,21 & 0,21 & 0,30 \\
\hline Kolin (\%) & 0,031 & 0,031 & 0,031 & 0,031 & 0,04 \\
\hline Aminovit (\%) & 0 & 0,5 & 1,0 & 1,5 & - \\
\hline
\end{tabular}

Keterangan:

1) Menurut rekomendasi NRC (2012)

\section{Rancangan Penelitian}

Rancangan yang digunakan dalam penelitian ini adalah rancangan acak lengkap (RAL) dengan empat perlakuan dan setiap perlakuan terdapat empat kali ulangan, sehingga dalam penelitian ini menggunakan 4 $\times 4$ ekor $=16$ ekor babi bali jantan lepas sapih. Perlakuan yang dicobakan kepada babi bali lepas sapih adalah perlakuan pakan yang terdiri atas: perlakuan Po: pakan dasar campuran jagung dan pollard; P1: perlakuan Po + 0,50\% Aminovit; P2: perlakuan Po + 1,00\% Aminovit; dan $\mathrm{P}_{3}$ : perlakuan $\mathrm{Po}+1,50$ Aminovit.

\section{Tempat dan Lama Waktu Penelitian}

Penelitian dilakukan di Dusun Batupas, Desa Padangsambian Kaja, Kecamatan Denpasar Barat, Denpasar (Bali). Lama penelitian 2 minggu untuk penyesuaian pakan percobaan dan kemudian dilanjutkan selama 12 minggu pengambilan data penelitian.

\section{Pengamatan dan Analisis Data}

Parameter pengamatan meliputi performans babi bali hasil percobaan selama 12 minggu. Performans babi bali tersebut terdiri atas: berat badan awal, berat badan akhir, petambahan berat badan, konsumsi ransum dan konversi ransum (FCR). Data-data hasil pengamatan kemudian dianalisis dengan analisis sidik ragam (analysis of variance), bila terdapat perbedaan yang nyata $(\mathrm{P}<0,05)$, maka analisis dilanjutkan dengan analisis Duncan's New Multiples Range Test (Steel dan Torrie, 1989).

\section{HASIL DAN PEMBAHASAN}

\section{Berat badan}

Berat badan awal babi percobaan menunjukkan tidak terdapat perbedaan yang nyata $(\mathrm{P}>0,05)$ diantara perlakuan A, B, C dan D (Tabel 5). Pada akhir penelitian atau setelah 12 minggu, berat badan pada babi perlakuan A (tanpa Amnovit) menjadi 27,69 kg. Penambahan Aminovit pada perlakuan B, C dan D berturut-turut sebesar 0,$5 ; 1,0$ dan 1,5\% mengakibatkan berat badan akhir pada perlakuan tersebut berturut-turut menjadi 32,80; 36,61 dan 38,31 kg (Tabel 5). Keadaan ini secara statistik menunjukkan perbedaan yang nyata $(\mathrm{P}<0,05)$ diantara semua perlakuan. Berat badan akhir babi yang mendapat perlakuan pakan tanpa penambahan Aminovit (A) paling rendah dibandingkan dengan babi yang mendapat perlakuan pakan dengan tambahan Aminovit. Hal ini disebabkan pada babi -babi tersebut hanya mendapatkan asupan protein sebesar $12 \%$ dan kekurangan asam-asam amino esensial seperti yang ditambahkan pada formula Aminovit (lisin dan metionin). Metionin merupakan asam amino pembatas walau diperlukan sedikit dibandingkan dengan lisin. Sebaliknya asam amino lisin diperlukan dalam persentase lebih besar dibandingkan denagn metionin. Asam amino esensial yang dibutuhkan oleh babi babi sebanyak 10 asam amino. Akan tetapi yang menjadi asam amino esensial yang kandungannya terbatas pada bahan pakan nabati adalah asam amino lisin 
$\left(\mathrm{H}_{2} \mathrm{~N}\left(\mathrm{CH}_{2}\right)_{4} \mathrm{CH}\left(\mathrm{NH}_{2}\right) \mathrm{CO}_{2} \mathrm{H}\right)$ dan metionin $\left(\mathrm{C}_{5} \mathrm{H}_{11} \mathrm{NO}_{2} \mathrm{~S}\right)$ (U.S. Pork Center of Excellence, 2010). Kebutuhan asam amino lisin sekitar $1,25-1,31 \%$ dan kebutuhan asam amino metionin sekitar 0,35-0,37\% dalam pakan pada babi dengan berat badan sekitar 10-15 kg (U.S. Pork Center of Excellence, 2010; NRC, 2012).

Tabel 5. Penampilan babi bali yang diberi ransum dengan suplementasi Aminovit

\begin{tabular}{llcccc}
\hline \multirow{2}{*}{ No. Variabel } & \multicolumn{4}{c}{ Perlakuan } \\
\cline { 2 - 5 } & A & B & C & D \\
\hline 1 Berat badan awal & $13,11 a^{2)}$ & $13,11 a$ & $13,17 a$ & $13,11 \mathrm{a}$ \\
2 & Berat badan akhir & $27,69 a$ & $32,80 b$ & $36,61 c$ & $38,31 d$ \\
3 & Pertambahan berat badan & $14,47 a$ & $19,68 b$ & $23,43 c$ & $25,19 d$ \\
4 & Konsumsi pakan & $79,29 a$ & $128,91 b$ & $131,79 c$ & $133,71 d$ \\
5 & FCR & $5,48 a$ & $3,93 b$ & $3,60 c$ & $3,49 d$ \\
\hline
\end{tabular}

Keterangan:

1) A: babi diberi pakan tanpa Aminovit; B: babi diberi pakan dengan $0,5 \%$ Aminovit; C: babi diberi pakan dengan 1,0\% Aminovit; D: babi diberi pakan dengan 1,5\% Aminovit

2) Nilai dengan huruf yang sama pada baris yng sama adalah bebeda tidak nyata $(P>0,05)$

\section{Pertambahan berat badan}

Pertambahan berat badan pada babi yang mendapat perlakuan A (tanpa Aminovit) sebesar 14,47 kg. Penambahan Aminovit pada perlakuan B, C dan D berturut-turut sebesar 0,$5 ; 1,0$ dan $1,5 \%$ mengakibatkan pertambahan berat badan pada perlakuan tersebut meningkat berturut-turut sebesar 19,68; 23,43 dan 25,19 kg. Peningkatan pertambahan berat badan ini secara statistik menunjukkan perbedaan yang nyata $(\mathrm{P}<0,05)$ diantara semua perlakuan. Kecukupan jumlah asupan asam-asam amino esensial dan kolin yang meningkat pada perlakuan B, C dan D mengakibatkan pertambahan berat badan yang semakin meningkat. Dengan penambahan Aminovit berarti akan lebih banyak disintesis protein tubuh sehingga berat badan dan pertambahan berat badan akan meningkat sebagai akibat deposit protein dalam jaringan tubuh babi. Pemberian vitamin (vitamin B4, kolin) direkomendasikan bahwa ditambahan 200 g kolin per ton pakan babi muda (NRC 1988).

\section{Konsumsi Pakan}

Konsumsi pakan pada babi yang mendapat perlakuan A (tanpa Aminvit) sebesar 79,29 kg. Penambahan Aminovit pada perlakuan B, C dan D berturut-turut sebesar 0,5; 1,o dan 1,5\% mengakibatkan konsumsi pakan pada perlakuan tersebut meningkat berturut-turut sebesar 128,91; 131,79; dan 133,71 kg. Peningkatan konsumsi pakan ini secara statistik menunjukkan perbedaan yang nyata $(\mathrm{P}<0,05)$ diantara semua perlakuan. Penambahan Aminovit akan mencukupi kebutuhan asam-asam amino esensial dan vitamin, sehingga petumbuhan babi muda lebih cepat. Pertumbuhan yang lebih cepat akibat dari deposit protein dan lemak di dalam jaringan tubuh babi, dimana deposit tersebut yang berasal dari nutriennutrien pakan yang dikonsumsi. Meningkatnya berat badan yang lebih tinggi sudah tentu akan diikuti dengan konsumsi pakan serta efisiensi pakan yang lebih tinggi pula.

\section{Konversi pakan}

Konversi pakan (feed conversion ratio, FCR) pada babi yang mendapat perlakuan A (tanpa Aminovit) sebesar $5,48 \mathrm{~kg}$. Penambahan Aminovit pada perlakuan $\mathrm{B}, \mathrm{C}$ dan $\mathrm{D}$ berturut-turut sebesar 0,$5 ; 1,0$ dan 1,5\% mengakibatkan FCR pada perlakuan tersebut menurun berturut-turut sebesar 3,93; 3,60, dan 3,49. Penurunan FCR tersebut secara statistik menunjukkan perbedaan yang nyata $(\mathrm{P}<0,05)$ diantara semua perlakuan. Penurunan FCR atau meningkatnya efisiensi penggunaan pakan untuk membentuk jaringanjaringan tubuh terlihat adanya penurunan angka FCR akibat penambahan Aminovit yang meningkat ke dalam ransum. Angka konversi pakan artinya jumlah pakan yang dibutuhkan untuk menghasilkan $1 \mathrm{~kg}$ pertambahan berat badan. Semakin kecil angka FCR berarti semakin sedikit pakan yang dibutuhkan untuk menaikkan $1 \mathrm{~kg}$ berat badan. Kecukupan nutiren-nutrien pakan bagi babi mengakibatkan pertumbuahn yang lebih cepat, berarti pertambahan berat badannya juga meningkat.

\section{SIMPULAN}

Dari hasil penelitian ini dapat disimpulkan bahwa penambahan Aminovit dalam pakan meningkatkan berat badan akhir, pertambahan berat badan, konsumsi pakan dan efisiensi penggunaan pakan.

\section{UCAPAN TERIMAKASIH}

Melalui kesempatan ini penulis mengucapkan terimakasih kepada Rektor Universitas Udayana, Ketua LPPM Universitas Udayana dan Dekan Fakultas Peternakan Universitas Udayana atas persetujuan dana penelitian PNBP Unud Tahun 2015 skim Hibah Grup Riset Tahun 2017. Demikian juga kepada para pihak yang terlibat dalam penelitian ini, penulis juga ucapkan terimakasih.

\section{DAFTAR PUSTAKA}

Nitis, I M. 1967. Makanan babi di Bali (A Preliminary Survey). Universitas Udayana. FKHP Bull. 013.

NRC, 1988. Nutrient Requirements of Swine. Edition 9. National Academies Press. United State Dept. of Agriculture, USA.

NRC. 2012. Nutrient Requirement of Swine. $10^{\text {th }} \mathrm{Ed}$. Rev. United State Dept. of Agriculture, USA. 
Patterson, K. Y., A. S. Bhagwat, J. R. Williams, J C. Howe and J. M. Holden. 2oo8. SDA Database for the Choline Content of Common Foods. Nutrient Data Laboratory Agricultural Research Service, U.S.Department of Agriculture, 10300 Baltimore Avenue, USA.

Southern, L.L., D.R. Brown , D.D. Werner and M.C. Fox. 1986. Excess supplemental choline for swine. J Anim Sci. Apr: 62(4): 992-6.

Sumadi I.K. Sumadi, I M. Suasta, I P. A. Astawa dan A. A. P. Wibawa 2017. Pengaruh Penambahan Campuran Asam Amino Esensial dan Kolin (Aminovit) dalam Pakan Tradisional Babi pada Bali Jantan. Prosiding
Senastek IV. Tanggal 14-15 Desember 2017, Patra Jasa Bali Risort and Villas, Kuta, Badung (Bali).

Sumadi, I K., I M. Suasta, dan I P. A. Astawa. 2015. Pengaruh Imbangan Energi dan Protein Ransum terhadap Performans Babi Bali. Prosiding Senastek II 2015: Inovasi Humaniora, Sains dan Teknologi untuk Pembangunan Berkelanjutan. Tanggal 29 -30 Oktober 2015, Patra Jasa Bali Risort and Villas, Kuta, Badung (Bali).

U.S. Pork Centre for Exellence. 2010. National Swine Nutrition Guide. U.S. Pork Center of Excellence. 1776 NW 114th St. Des Moines, IA 50325. 